\title{
PENGEMBANGAN MEDIA KOKAMI PADA PEMBELAJARAN TEMATIK DI KELAS V SEKOLAH DASAR KECAMATAN PEMENANG
}

\author{
Lalu Yani Faturrahman ${ }^{1}$, Ida Ermiana ${ }^{2}$, Baiq Niswatul Khair ${ }^{3}$ \\ ${ }^{1,2,3}$ Program Studi Pendidikan Guru Sekolah Dasar, Universitas Mataram, Mataram, Indonesia
}

\section{Informasi Artikel}

Riwayat Artikel:

Diserahkan: 12-12-2020

Direvisi: 21-12-2020

Dipublikasikan: 11-01-2021

\section{Kata-kata kunci:}

Pengembangan

Media

Kokami

Pembelajaran

Tematik

\begin{abstract}
ABSTRAK
Penelitian ini bertujuan untuk mengetahui kelayakan media Kokami sebagai media pembelajaran menurut validasi ahli dan uji coba terbatas. Jenis penelitian ini adalah R\&D (Research and Development) dengan model pengembangan 4-D dari Thiagarajan yang terdiri dari empat tahap yaitu define (pendefinisian), design (perancangan), develop (pengembangan), dan disseminate (penyebaran). Instrumen yang digunakan berupa kuesioner validasi ahli media, validasi ahli materi, respon guru, dan respon siswa. Rata-rata jumlah skor $(X)$ yang diperoleh dari validasi ahli media tahap II sebesar 99 yang terletak pada interval $X>92.4$, sehingga termasuk dalam kategori sangat layak. Rata-rata jumlah skor $(X)$ yang diperoleh dari validasi ahli materi tahap II sebesar 92 yang terletak pada interval $X>79.8$, sehingga termasuk dalam kategori sangat layak. Rata-rata jumlah skor $(X)$ yang diperoleh dari respon guru sebesar 144 yang terletak pada interval $X>126$, sehingga termasuk dalam kategori sangat layak. Rata-rata jumlah skor $(X)$ yang diperoleh dari respon siswa sebesar 55 yang terletak pada interval $X>50.4$, sehingga termasuk dalam kategori sangat layak. Dengan demikian, dapat disimpulkan bahwa pengembangan media pembelajaran Kokami pada pembelajaran tematik sudah mememenuhi kategori kelayakan untuk digunakan sebagai media pembalajaran.
\end{abstract}

This is an open access article under the CC BY-SA license.

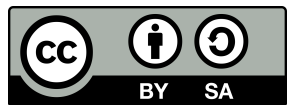

\section{Penulis Korespondensi:}

Lalu Yani Faturrahman,

Program Studi Pendidikan Guru Sekolah Dasar, Universitas Mataram,

J1. Brawijaya No.22, Cakranegara, Kota Mataram, Indonesia.

Email: yanifaturrahman.lyf@gmail.com

\section{PENDAHULUAN}

Saat ini pada jenjang pendidikan sekolah dasar secara merata telah menerapkan Kurikulum 2013 yang berorientasi pada pembelajaran tematik sebagai pendekatan pembelajaran. Pembelajaran tematik merupakan model dari kurikulum terpadu yang menggunakan tema untuk mengaitkan beberapa mata pelajaran sehingga dapat memberikan pengalaman bermakna bagi siswa (Akbar et al., 2016). Pembelajaran tematik memadukan berbagai mata pelajaran dalam kurikulum dan menghubungkannya melalui jaringan topik atau tema (Erfan, Maulyda, Ermiana, Hidayati, \& Ratu, 2020). Dengan adanya pemaduan itu, siswa akan memperoleh pengetahuan dan keterampilan secara utuh sehingga pembelajaran jadi bermakna.

Ciri khas materi pembelajaran pada tingkat sekolah dasar adalah pembelajaran tematik (Erfan, Widodo, Umar, Radiusman, \& Ratu, 2020). Adapun di dalam pembelajaran tematik diperlukannya sebuah media pembelajaran untuk menunjang kelangsungan pembelajaran dan dapat mempermudah siswa untuk memahami 
materi yang disampaikan oleh guru, serta dapat melibatkan siswa untuk turut aktif dalam kegiatan pembelajaran yang berlangsung. Dalam suatu proses belajar mengajar, dua unsur yang amat penting adalah metode mengajar dan media pembelajaran (Turrahmi, Erfan, \& Yahya, 2017). Oleh karena itu guru hendaknya berupaya mewujudkan proses pembelajaran tematik yang kreatif, inovatif, efektif dan menyenangkan sehingga dalam suasaSna pembelajaran menjadi lebih kondusif. Hal ini akan tercapai apabila pemilihan media pembelajaran yang tepat karena dengan adanya media dapat menambah kualitas pembelajaran yang nantinya akan membuat siswa dengan cepat menyerap materi yang diberikan guru.

Berbicara soal media pembelajaran, media pembelajaran adalah segala sesuatu yang dapat menarik perhatian dan minat siswa ketika belajar, sehingga siswa menjadi bertambah rasa ingin tahunya untuk memahami pelajaran. Tercapainya tujuan pembelajaran tidak terlepas dari peran penting media pembelajaran. Media pembelajaran adalah segala alat pembelajaran yang digunakan untuk membantu menyampaikan materi dalam proses pembelajaran sehingga memudahkan pencapaian tujuan pembelajaran yang telah dirumuskan (Ermiana, Witono, \& Khair, 2019). Media pembelajaran dalam proses pembelajaran dapat membangkitkan kemauan, minat, motivasi dan rangsangan kegiatan belajar, bahkan dapat membawa pengaruh psikologis terhadap siswa (Handhika, 2012). Oleh karena itu guru dituntut untuk terampil dalam membuat dan menggunakan media yang bervariasi agar siswa tidak mudah bosan dan dapat terlibat aktif dalam pembelajaran.

Namun pada kenyataannya, banyak guru yang tidak menggunakan media pembelajaran secara maksimal. Berdasarkan hasil observasi yang dilakukan di SDN 8 Pemenang Barat, selama proses pembelajaran guru lebih sering menggunakan buku tema sehingga dirasa masih terdapat kelemahan dalam penggunaannya. Salah satunya, siswa tidak begitu tertarik untuk membaca buku tersebut. Pernyataan ini didukung oleh hasil wawancara yang dilakukan dengan guru kelas $\mathrm{V}$ di SD tersebut, beliau menyatakan bahwa memang sebagian besar guru lebih sering mengandalkan media seadanya berupa buku tema sebagai pegangan untuk memberikan materi pada siswa. Salah satu kendala yaitu kurangnya kemampuan guru dalam membuat media pembelajaran, beberapa diantaranya juga memiliki kesibukan diluar pembelajaran sehingga waktu untuk menyiapkan dan membuat media pembelajaran sangat terbatas.

Selain itu, guru sudah menggunakan model dan metode misalnya berupa ceramah, tanya jawab dan diskusi. Awalnya pembelajaran di kelas berjalan dengan baik. Akan tetapi, beberapa saat kemudian terlihat bahwa siswa kurang fokus, beberapa siswa mulai mengalihkan perhatiannya pada hal yang lain seperti mengganggu temannya, mengobrol, melamun bahkan ada yang mengantuk. Kasus tersebut menunjukkan bahwa pembelajaran berjalan kurang menarik dan membosankan bagi siswa.

Berdasarkan permasalahan yang telah diuraikan tersebut, maka perlu adanya perbaikan dan modifikasi pembelajaran di kelas. Salah satu cara untuk memperbaiki kondisi pembelajaran tersebut yaitu dengan melakukan perubahan melalui pengembangan media pembelajaran. Media tersebut diharapkan mampu menumbuhkan suasana belajar yang baru sehingga mendapatkan respon positif dari siswa. Oleh karena itu, perlu dikembangkannya sebuah media pembelajaran yang dapat menarik perhatian dan melibatkan siswa secara interktif, salah satunya adalah media Kokami.

Menurut Kadir dalam Rusiana (2014), media Kokami merupakan jenis media yang dikombinasikan dengan permainan bahasa. Permainan ini merupakan salah satu alternatif, selain untuk menambah pengetahuan siswa dengan menarik dan menyenangkan, juga dapat berfungsi untuk merangsang minat dan motivasi belajar siswa. Seperti namanya, Kokami terdiri dari suatu kotak yang di dalamnya terdapat berbagai kartu pesan. Pesan tersebut dapat berupa perintah, pertanyaan dan hukuman yang ditulis pada potongan kertas karton yang dimasukkan kedalam amplop tertutup. Kartu-kartu tersebut merupakan komponen penting dalam permainan menggunakan media Kokami, karena arah kegiatan belajar mengajar tertuang di dalamnya. Adapun di dalam penggunaannya, peran guru hanya sebagai pemberi instruksi.

Media Kokami juga memiliki beberapa kelebihan, yaitu alat dan bahannya mudah dan murah, cara pembuatannya mudah, bentuknya sederhana, serta mudah digunakan oleh guru dan siswa. Selain itu, menurut Suryadi (2013) media Kokami juga memiliki kelebihan yaitu, menanamkan pengetahuan kepada siswa secara menarik dan berkesan, serta merangsang minat dan perhatian siswa. Dengan kelebihan yang dimiliki, media ini dapat dibuat dan digunakan oleh guru sebagai sarana yang dapat membantu dalam proses pembelajaran. Media ini sebelumnya tidak pernah digunakan oleh guru dalam kegiatan pembelajaran di kelas. Dengan adanya media tersebut diharapkan sebagai solusi dari permasalahan yang dihadapi guru maupun siswa sehingga pembelajaran menjadi lebih menarik dan menyenangkan.

Berdasarkan penelitian yang dilakukan oleh Marwati (2018) dengan judul penelitian "Pengembangan Media Kokami Dalam Pembelajaran IPS Pada Siswa Kelas IV SDN Purut Kecamatan Curug Kota Serang”. Se- 
lain itu, penelitian yang dilakukan oleh Gammara dan Subroto (2019) dengan judul penelitian "Pengembangan Media Pembelajaran Kotak dan Kartu Misterius untuk Meningkatkan Hasil Belajar Siswa pada Mata Pelajaran Ekonomi Kelas X SMA”. Hasil dari kedua penelitian tersebut menunjukkan bahwa media Kokami sangat layak digunakan sebagai media pembelajaran. Adapun media Kokami yang akan dikembangkan pada penelitian ini tidak jauh berbeda dari peneliti-peneliti sebelumnya, hanya saja terdapat beberapa bagian yang menjadi pembeda yaitu terletak pada tingkatan kelas dan pembelajaran. Selain itu, terdapat beberapa penambahan pada jenis kartu dan desain media Kokami.

Berdasarkan paparan di atas, maka penelitian pengembangan yang berjudul "Pengembangan Media Kokami pada Pembelajaran Tematik di Kelas V SD Kecamatan Pemenang” perlu dilakukan. Penelitian ini akan mencoba mengembangkan media Kokami dengan maksud mengetahui kelayakan media tersebut sehingga dapat digunakan sebagai media pembelajaran.

\section{METODE PENELITIAN}

Penelitian ini merupakan penelitian pengembangan atau lebih dikenal dengan Research and Development (R\&D). Penelitian ini bertujuan untuk menhasilkan produk yang layak untuk digunakan berdasarkan penilaian dari ahli. Berdasarkan produk yang dikembangkan pada penelitian ini yakni sebuah media pembelajaran, maka pengembangan produk mengacu pada model pengembangan dari Thiagarajan yang dikenal dengan model 4-D. Sebagaimana pendapat Wiyono (2017) bahwa model pengembangan 4-D sangat cocok untuk pengembangan media Kokami dan langkah penelitian tersusun secara sistematis sehingga peneliti dapat mengontrol masing-masing langkah dengan baik. Model tersebut dilakukan melalui 4 tahap, yaitu define (pendefinisian), design (perancangan), develop (pengembangan), dan disseminate (penyebaran).

Subjek dalam penelitian pengembangan ini adalah 6 orang siswa kelas V SD di Kecamatan Pemenang yang memiliki kemampuan beragam, yaitu 2 siswa berkemampuan rendah, 2 siswa berkemampuan sedang, dan 2 siswa berkemampuan tinggi. Hal tersebut dilakukan karena, uji coba produk hanya pada uji kelompok kecil. Selain itu, mengingat pada masa COVID-19 ini tidak memungkinkan untuk memilih subjek penelitian dalam jumlah banyak, sehingga peneliti berinisiatif untuk memilih subjek dengan jumlah terbatas.

Jenis data yang digunakan berupa data kuantitatif dan kualitatif. Data kuantitatif diperoleh dari hasil validasi ahli media, validasi ahli materi, respon guru, dan respon siswa. Sedangkan data kualitatif diperoleh dari masukan dan saran para ahli pada tahapan validasi produk. Instrumen pengumpulan data yang digunakan berupa kuesioner. Kuesioner tersebut terdiri dari sejumlah pernyataan tertulis yang diberikan kepada sejumlah responden untuk memperoleh informasi terkait penelitian yang dilakukan. Kuesioner digunakan untuk mengetahui hasil validasi ahli media, ahli materi, respon guru, dan respon siswa dengan menggunakan skala likert yang diisi dengan memberikan checlist $(\sqrt{ })$ pada kokam yang tersedia. Data yang dianalisis adalah data yang didapatkan dari lembar validasi ahli media, validasi ahli materi, respon guru, dan respon siswa. Lembar kuesioner tersebut dianalisis secara deskriptif kuantitatif.

\section{HASIL DAN PEMBAHASAN}

\subsection{Hasil Penelitian}

Penelitian ini menghasilkan produk berupa media pembelajaran Kokami (Kotak dan kartu misteri) pada pembelajaran tematik khususnya materi penggolongan hewan berdasarkan jenis makanannya. Media tersebut dikembangkan berdasarkan model 4-D Thiagarajan yang terdiri dari empat tahap yaitu define, design, develop, dan disseminate.

\subsubsection{Tahapan Define}

Melalui tahapan define, dianalisis mengenai kebutuhan pembelajaran pada kurikulum 2013. Langkah yang dilakukan mulai dari analisis awal yang bertujuan untuk menetapkan masalah dasar yang dihadapi dalam pembelajaran di sekolah yang meliputi permasalahan yang ada di sekolah sehingga dibutuhkan pengembangan media pembelajaran. Kemudian melakukan analisis siswa untuk mengetahui karakteristik siswa yang meliputi latar belakang pengetahuan dan perkembangan kognitif siswa. Selanjutnya melakukan analisis materi, analisis konsep, dan spesifikasi tujuan pembelajaran dengan tujuan untuk mengidentifikasi, merinci dan menyusun materi-materi utama yang akan dipelajari siswa serta merumuskan tujuan-tujuan pembelajaran yang harus dicapai oleh siswa. Hasil dari serangkaian langkah tersebut kemudian menjadi dasar untuk merancang media pembelajaran yang akan dikembangkan. 
Berdasarkan hasil pada tahap define, ditetapkan media yang hendak dibuat sebagai media pembelajaran pada tema $\mathrm{V}$ khususnya materi penggolongan hewan berdasarkan jenis makanannya adalah media Kokami. Media ini dapat dikombinasikan dengan permainan. Permainan tersebut dapat dimainkan secara berkelompok. Adapun media yang dikembangkan tersebut terdiri dari beberapa komponen, yaitu kartu, amplop, dan kotak serta pedoman media Kokami sebagai tambahan. Oleh karena itu, pada tahap design dibuat rancangan awal media (prototipe 1) dengan menentukan tampilan, bahan dan ukuran dari komponen-komponen yang telah disebutkan tersebut.

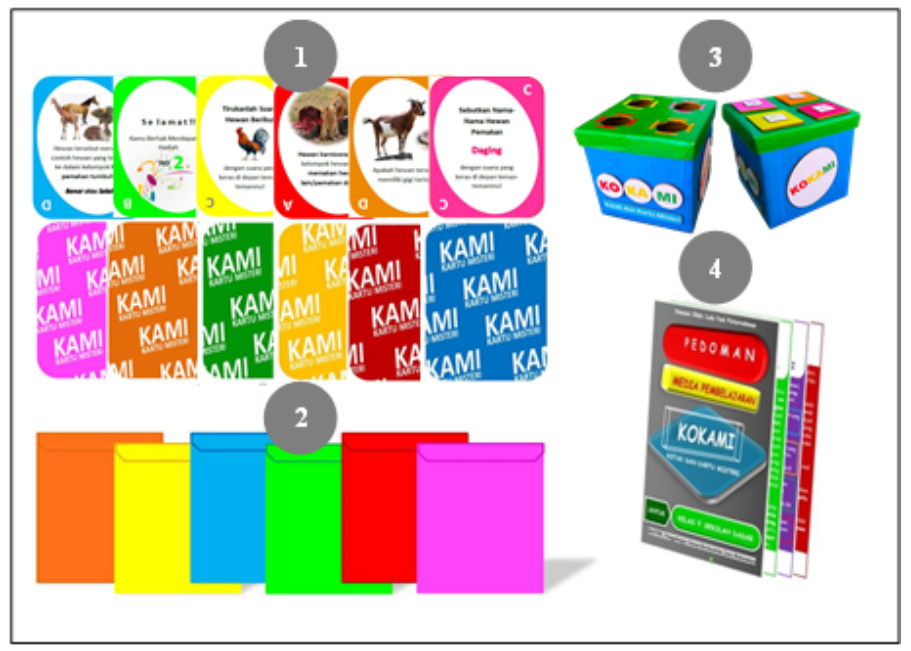

Gambar 1. Komponen Media Kokami

Komponen pertama yaitu kartu yang merupakan komponen terpenting dalam media Kokami sebagaimana dijelaskan oleh Rusiana (2014) bahwa kartu merupakan komponen yang paling penting dalam media ini karena arah kegiatan belajar mengajar tertuang di dalamnya. Komponen kedua yaitu amplop yang berfungsi sebagai wadah kartu misteri. Ukuran dan warna amplop menyesuaikan dengan kartu misteri. Komponen ketiga yaitu kotak yang berfungsi untuk menampung kartu-kartu misteri. Kotak didesain menjadi 4 bagian dengan tujuan agar siswa tidak keliru pada saat mengambil kartu yang diperintahkan. Adapun komponen tambahan yaitu pedoman media yang berfungsi untuk mengarahkan pengguna dalam menggunakan media Kokami.

\subsubsection{Tahapan Design}

Desain tampilan dari media secara keseluruhan menggunakan Microsoft Office Word 2010. Materi yang dimuat dalam media ini adalah materi penggolongan hewan berdasarkan jenis makanannya yang terdiri dari herbivora, karnivora, dan omnivora. Materi disesuaikan dengan KD yang terdapat pada buku tema V K13 yang tersedia di sekolah. Adapun gambar-gambar yang terdapat pada kartu didownload dari google. Secara umum media Kokami dibuat dengan warna yang beragam agar lebih menarik.

\subsubsection{Tahapan Develop}

Selanjutnya adalah tahap develop. Tahap ini bertujuan untuk menghasilkan media Kokami yang sudah direvisi berdasarkan masukan ahli, dalam hal ini adalah ahli media dan ahli materi serta uji coba terbatas, bertujuan untuk mengetahui tanggapan dari siswa dan guru terhadap media yang dikembangkan dengan mengisi kuesioner respon.

Validasi ahli media dilakukan sebanyak dua tahap. Hasil validasi media Kokami tahap I dan II dapat dilihat pada Tabel 1 .

Tabel 1. Hasil Validasi Ahli Media Tahap I dan II

\begin{tabular}{cccccc}
\hline \multirow{2}{*}{ Tahapan } & \multirow{2}{*}{$\begin{array}{c}\text { Jumlah } \\
\text { Responden }\end{array}$} & \multicolumn{3}{c}{ Skor yang Diperoleh } & \multirow{2}{*}{ Kategori } \\
\cline { 3 - 5 } & 1 & 84 & 84 & Rerata Skor & \\
Tahap I & 1 & 99 & 99 & 3.82 & Layak \\
Tahap II & 1 & Rata-Rata Jumlah Skor (X) & Sangat Layak \\
\hline
\end{tabular}


Berdasarkan Tabel 1 terlihat bahwa pada validasi tahap I mendapatkan jumlah skor rata-rata $(X)$ sebesar 84 di mana nilai tersebut terletak pada interval $74.8<X \leq 92.4$ sehingga interpretasi dari penilaian tersebut termasuk dalam kategori layak dengan rerata skor 3,818, sedangkan pada validasi tahap II mendapatkan peningkatan jumlah skor rata-rata $(X)$ yaitu sebesar 99 di mana nilai tersebut terletak pada interval $X>$ 92.4 sehingga interpretasi dari penilaian tersebut termasuk dalam kategori sangat layak dengan rerata skor 4.5. Peningkatan jumlah skor rata-rata $(X)$ pada tahap II didapatkan setelah dilakukannya revisi/perbaikan pada media berdasarkan masukan dan saran dari validator.

Validasi ahli materi dilakukan sebanyak dua tahap. Hasil validasi materi tahap I dan II dapat dilihat pada Tabel 2.

Tabel 2. Hasil Validasi Ahli Materi Tahap I dan II

\begin{tabular}{cccccc}
\hline \multirow{2}{*}{ Tahapan } & Jumlah & \multicolumn{3}{c}{ Skor yang Diperoleh } & \multirow{2}{*}{ Kategori } \\
\cline { 3 - 5 } & Responden & Jumlah Skor & Rata-Rata Jumlah Skor (X) & Rerata Skor & \\
\hline Tahap I & 1 & 86 & 86 & 4.53 & Sangat Layak \\
Tahap II & 1 & 92 & 99 & 4.84 & Sangat Layak \\
\hline
\end{tabular}

Berdasarkan Tabel 2 terlihat bahwa pada validasi tahap I mendapatkan jumlah skor rata-rata $(X)$ sebesar 86 di mana nilai tersebut terletak pada interval $X>79.8$ sehingga interpretasi dari penilaian tersebut termasuk dalam kategori sangat layak dengan rerata skor 4.526, sedangkan pada validasi tahap II mendapatkan peningkatan jumlah skor rata-rata $(X)$ yaitu sebesar 92 di mana nilai tersebut terletak pada interval $X>79.8$ sehingga interpretasi dari penilaian tersebut termasuk dalam kategori sangat layak dengan rerata skor 4.842. Peningkatan jumlah skor rata-rata $(X)$ pada tahap II didapatkan setelah dilakukannya perbaikan pada materi berdasarkan masukan dan saran dari validator.

Kuesioner respon siswa pada uji coba terbatas terdiri dari 12 item pernyataan yang terbagi kedalam dua aspek yaitu, aspek materi berjumlah 5 item pernyataan dan aspek media berjumlah 7 item pernyataan dengan jumlah responden 6 orang. Hasil kuesioner respon siswa ditampilkan dalam bentuk tabel dan diagram sebagai berikut.

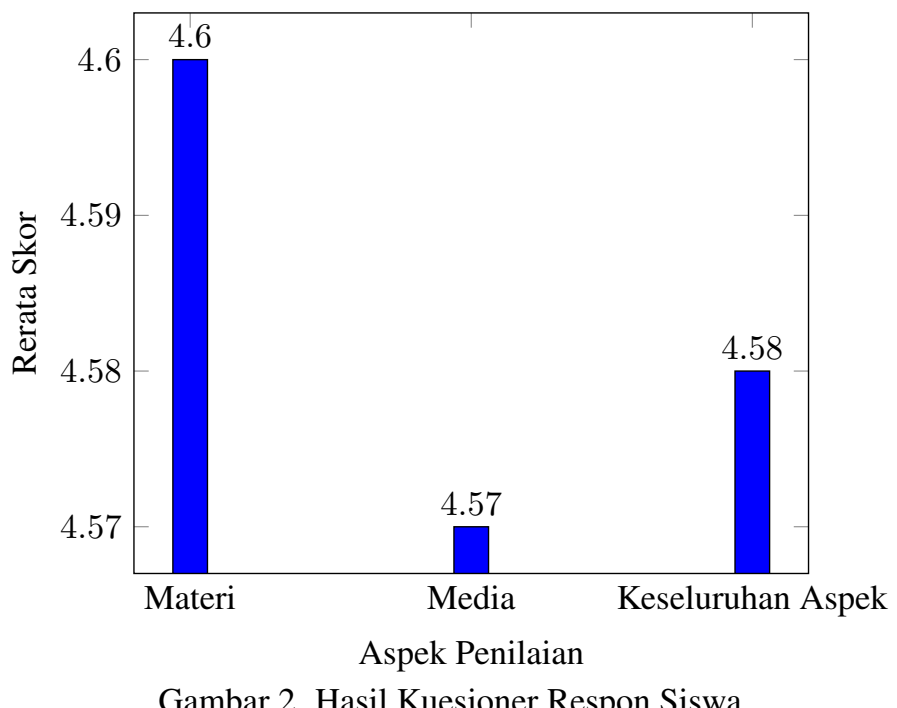

Berdasarkan Gambar 2 menyatakan bahwa rata-rata jumlah skor $(X)$ dari aspek materi mendapatkan skor sebesar 23 di mana nilai tersebut terletak pada interval $X>20.999$ sehingga interpretasi dari penilaian tersebut termasuk dalam kategori sangat layak dengan rerata skor 4.6. Sedangkan rata-rata jumlah skor dari aspek media mendapatkan skor $(X)$ sebesar 32 di mana nilai tersebut terletak pada interval $X>29.4$ sehingga interpretasi dari penilaian tersebut termasuk dalam kategori sangat layak dengan rerata skor 4.571. Adapun rata-rata jumlah skor $(X)$ dari keseluruhan aspek mendapatkan skor sebesar 55 di mana nilai tersebut terletak pada interval $X>50.4$ sehingga interpretasi dari penilaian tersebut termasuk dalam kategori sangat layak dengan rerata skor 4.583 . 
Kuesioner respon guru pada uji coba terbatas terdiri dari 30 item pernyataan yang terbagi kedalam dua aspek yaitu aspek media berjumlah 16 item pernyataan dan aspek materi berjumlah 14 item pernyataan dengan satu responden. Hasil kuesioner respon guru ditampilkan dalam bentuk tabel dan diagram sebagai berikut.

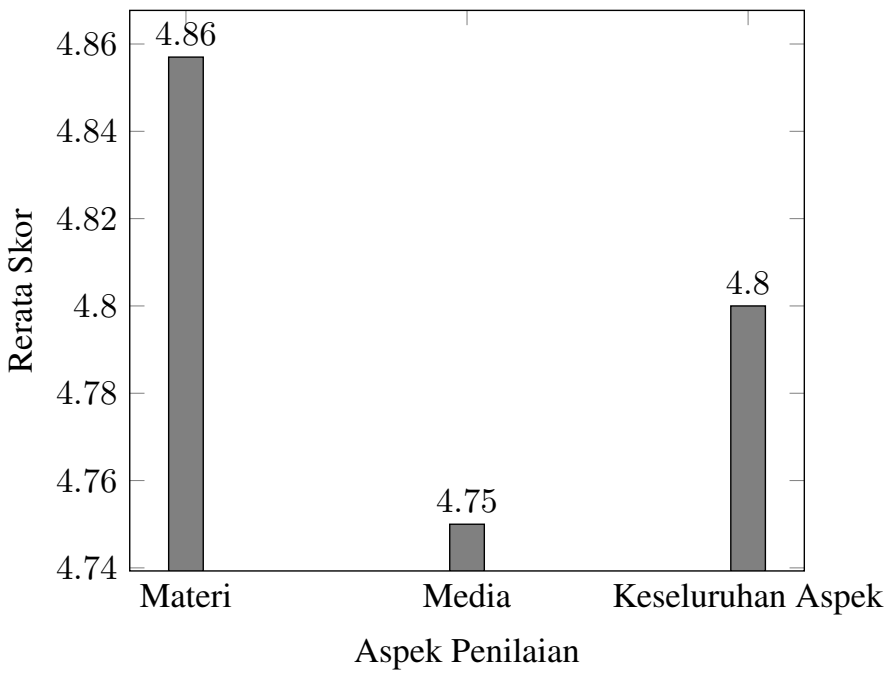

Gambar 3. Hasil Kuesioner Respon Guru

Berdasarkan hasil kuesioner respon guru pada Gambar 3 dapat dilihat bahwa rata-rata jumlah skor $(X)$ dari aspek media mendapatkan skor sebesar 76 di mana nilai tersebut terletak pada interval $X>67.2$ sehingga interpretasi dari penilaian tersebut termasuk dalam kategori sangat layak dengan rerata skor 4.75. Sedangkan rata-rata jumlah skor dari aspek materi mendapatkan skor $(X)$ sebesar 68 di mana nilai tersebut terletak pada interval $X>58.799$ sehingga interpretasi dari penilaian tersebut termasuk dalam kategori sangat layak dengan rerata skor 4.857. Adapun rata-rata jumlah skor $(X)$ dari keseluruhan aspek mendapatkan skor sebesar 144 di mana nilai tersebut terletak pada interval $X>126$ sehingga interpretasi dari penilaian tersebut termasuk dalam kategori sangat layak dengan rerata skor 4.8.

\subsubsection{Tahapan Disseminate}

Tahap terakhir adalah tahap disseminate. Pada tahap ini produk yang dikembangkan dapat disebarluaskan agar dapat dipergunakan dalam skala yang lebih luas. Tahap penyebaran dalam penelitian pengembangan media Kokami (Kotak dan kartu misteri) ini hanya dapat dilakukan dalam skala kecil dengan mensosialisasikan media Kokami kepada guru SDN 8 Pemenang Barat terutama guru kelas V. Media tersebut kemudian diserahkan sebagai hasil dari tahap penyebaran yang dilakukan.

\subsection{Pembahasan}

Berdasarkan hasil analisis pada tahap pertama yaitu define, dapat disimpulkan bahwa media pembelajaran memiliki peranan yang sangat penting dalam kegiatan belajar mengajar. Salah satu faktor penentu keberhasilan belajar siswa adalah media pembelajaran yang digunakan oleh seorang guru. Sejalan dengan pendapat Handhika (2012) bahwa, penggunaan media pembelajaran dalam proses pembelajaran dapat membangkitkan kemauan, minat, motivasi dan rangsangan kegiatan belajar, bahkan dapat membawa pengaruh psikologis terhadap siswa.

Selain itu, media merupakan perantara atau pengantar pesan dari pengirim pesan ke penerima pesan (komunikasi). Dengan demikian, Qamariah (2017) menyebutkan bahwa, komunikasi yang terjadi dalam kelas akan menjadi lebih baik jika ditambah dengan adanya media, melalui media pembelajaran, proses belajar mengajar yang terjadi juga menjadi optimal. Media pembelajaran sangat bermanfaat sebagai alat atau perantara untuk mendapatkan hasil belajar yang lebih optimal bagi siswa, baik itu pengetahuan, keterampilan, dan sikap. Oleh karena itu, mengingat media sangat bermanfaat dalam proses pembelajaran terutama bagi guru dan siswa, maka para guru harus bisa menggunakannya untuk menciptakan suasana pembelajaran yang lebih baik (Darnawati, Jamiludin, Mursidin, \& Yuniar, 2016).

Pada tahap design, peneliti mendesain awal media dengan menentukan komponen-komponen media Kokami, seperti kartu, amplop, dan kotak serta buku pedoman media kokami sebagai tambahan. Setelah 
menentukan komponen-komponen tersebut, selanjutnya menentukan tampilan/bentuk, ukuran, dan bahan yang akan digunakan untuk membuat rancangan awal (prototipe 1). Secara umum media Kokami dibuat dengan warna yang beragam agar lebih menarik. Warna memiliki daya tarik tersendiri, sebagaimana dijelaskan oleh Purnama (2010:127) bahwa, secara psikologis maupun estetis, warna memiliki makna yang mendalam.

Pada tahap develop, media yang telah dikembangkan kemudian divalidasi oleh beberapa ahli sebelum diuji cobakan. Validasi dilakukan oleh ahli media dan ahli materi yang ahli dibidangnya. Adapun tujuan dari validasi menurut Zulham dan Sulisworo (2017) adalah untuk mendapatkan saran dan masukan mengenai media pembelajaran yang dikembangkan. Hasilnya dijadikan sebagai pedoman dalam proses revisi/perbaikan. Hasil revisi akan dijadikan sebagai rancangan media yang akan diujicobakan secara terbatas.

Hasil validasi oleh validator menunjukkan bahwa, jumlah skor rata-rata $(X)$ sebesar 99 dengan rerata skor 4.5 untuk keseluruhan aspek pada validasi media dan jumlah skor rata-rata $(X)$ sebesar 92 dengan rerata skor 4.842 untuk keseluruhan aspek pada validasi materi berada pada kategori valid. Oleh karena itu, berdasarkan hasil validasi oleh validator, maka media pembelajaran yang telah dikembangkan dapat dikategorikan telah valid. Sejalan dengan penelitian yang dilakukan oleh Gammara dan Subroto (2019) yang menyatakan bahwa, hasil perhitungan validasi media dan materi dikatakan memenuhi kriteria interpretasi dan kriteria sangat layak. Apabila hasil analisis sesuai dengan kriteria yang telah ditentukan sebelumnya, maka media pembelajaran dikatakan valid. Sebagaimana dijelaskan oleh Arikunto (2013), sebuah media pembelajaran dikatakan valid jika hasilnya sesuai dengan kategori, dalam arti memiliki kesesuaian antara hasil instrumen dengan kategori yang telah ditentukan sebelumnya. Karena semua aspek penilaian terhadap media berada pada kategori sangat valid, maka media pembelajaran yang telah dikembangkan dapat digunakan pada tahap selanjutnya, yaitu uji coba terbatas. Namun demikian, saran dan masukan yang diberikan validator pada setiap item yang divalidasi, perlu dilakukan perbaikan-perbaikan seperlunya sesuai dengan catatan yang diberikan. Adapun saran dari para validator yang perlu perbaikan dalam media Kokami yang dibuat yakni; 1) Sebaiknya kartu dibuat dengan bahan kertas yang agak tebal agar tidak mudah sobek, atau dengan cara dilaminating, karena media akan digunakan, 2) Tambahkan gambar pada setiap kartu yang sekiranya membutuhkan gambar untuk memperjelas materi maupun soal-soal yang disampaikan. Salah satu kategori media yang valid/layak dipilih adalah media yang sejalan dan sesuai dengan kebutuhan pembelajaran. Hal ini juga sejalan dengan pendapat Sutikno bahwa, media layak digunakan apabila mendukung isi materi pembelajaran (Sinurat, Syahputra, \& Rajagukguk, 2015).

Adapun hasil pada uji coba terbatas yang melibatkan 6 siswa dan 1 guru kelas V SDN 8 Pemenang Barat memperoleh hasil positif. Berdasarkan hasil kuesioner respon siswa dari keenam responden, keseluruhan aspek memperoleh rata-rata jumlah skor $(X) 55$ di mana nilai tersebut terletak pada interval $X>50.4$ sehingga interpretasi dari penilaian tersebut termasuk dalam kategori sangat layak dengan rerata skor 4.583. Berdasarkan hasil kuesioner respon guru, keseluruhan aspek memperoleh rata-rata jumlah skor $(X) 144$ dimana nilai tersebut terletak pada interval $X>126$ sehingga interpretasi dari penilaian tersebut termasuk dalam kategori sangat layak dengan rerata skor 4.8. Dengan demikian kategori kelayakan terhadap media pembelajaran yang dikembangkan tercapai, sehingga dapat disimpulkan bahwa media pembelajaran Kokami praktis untuk digunakan sebagai media pembelajaran.

Secara keseluruhan, media pembelajaran berupa media Kokami (Kotak dan Kartu Misteri) yang telah dikembangkan memperoleh tanggapan positif baik dari validator, guru maupun siswa dengan kategori sangat valid sehingga dapat digunakan sebagai media pembelajaran dalam menunjang proses pembelajaran. Hal tersebut dikarenakan media Kokami berbentuk kartu yang dinamis dan fleksibel yang menggabungkan anatara bermain dengan belajar, sehingga tidak hanya menyenangkan untuk dimainkan, namun juga menambah pemahaman materi bagi siswa. Sejalan dengan pendapat Kadir dalam Muhaiminah (2018) bahwa, permainan Kokami menjadi salah satu alternatif, selain untuk menanamkan pengetahuan kepada siswa dengan menarik dan berkesan, juga berfungsi merangsang minat dan perhatian siswa untuk terlibat aktif dalam proses pembelajaran yang berlangsung. Selain itu, tampilan dari media tersebut menarik dengan menyajikan sentuhan warna-warna yang khas bagi siswa SD yang dapat membuat siswa tertarik untuk belajar.

\section{SIMPULAN}

Berdasarkan hasil validasi ahli media dan validsi ahli materi dapat disimpulkan bahwa media Kokami yang dikembangkan dinyatakan valid dan layak digunakan sebagai media pembelajaran. Hasil validasi ahli media tahap II pada keseluruhan aspek mendapatkan rata-rata jumlah skor $(X)$ sebesar 99, sedangkan hasil validasi ahli materi pada tahap II pada keseluruhan aspek mendapatkan rata-rata jumlah skor $(X)$ sebesar 92 . Hasil 
tersebut menunjukkan bahwa media Kokami termasuk dalam kategori sangat valid sehingga termasuk dalam kategori sangat layak. Adapun, berdasarkan hasil respon siswa dari 6 responden pada uji coba terbatas, keseluruhan aspek mendapatkan rata-rata jumlah skor $(X)$ sebesar 55, berdasarkan hasil respon, keseluruhan aspek mendapatkan rata-rata jumlah skor $(X)$ sebesar 144. Dengan demikian kategori kelayakan terhadap media pembelajaran yang dikembangkan tercapai, sehingga dapat disimpulkan bahwa media pembelajaran Kokami layak untuk digunakan sebagai media pembelajaran khususnya pada materi penggolongan hewan berdasarkan jenis makanannya di kelas V SD.

\section{DAFTAR PUSTAKA}

Akbar, S., A'yun, I. Q., Satriyani, F. Y., Widodo, W., Paranimmita, R., \& Ferisa, D. (2016). Implementasi Pembelajaran Tematik di Sekolah Dasar. Bandung: PT. Remaja Rosdakarya.

Arikunto, S. (2013). Dasar-Dasar Evaluasi Pendidikan. Jakarta: Bumi Aksara.

Darnawati, D., Jamiludin, J., Mursidin, M., \& Yuniar, N. (2016). Learning Through Media Development Model Application Assure. IOSR Journal of Humanities And Social Science, 21(11), 20-25. doi:10.9790/08372111032025

Erfan, M., Maulyda, M. A., Ermiana, I., Hidayati, V. R., \& Ratu, T. (2020). Profil Kemampuan Pembedaan Rangkaian Seri dan Paralel Calon Guru Sekolah Dasar. Edu Sains Jurnal Pendidikan Sains \& Matematika, 8(1), 13-21. doi:10.23971/eds.v8i1.1907

Erfan, M., Widodo, A., Umar, U., Radiusman, R., \& Ratu, T. (2020). Pengembangan Game Edukasi Kata Fisika Berbasis Android untuk Anak Sekolah Dasar pada Materi Konsep Gaya. Lectura: Jurnal Pendidikan, 11(1), 31-46.

Ermiana, I., Witono, A. H., \& Khair, B. N. (2019). Pengembangan Media Berdasar Komputer (CBI) untuk Meningkatkan Hasil Belajar IPA Siswa Kelas III di SDN 12 Ampenan. In Prosiding seminar nasional pagelaran pendidikan dasar nasional (ppdn) (pp. 297-303).

Gammara, S. A., \& Subroto, W. T. (2019). Pengembangan Media Pembelajaran Kotak dan Kartu Misterius untuk Meningkatkan Hasil Belajar Siswa pada Mata Pelajaran Ekonomi Kelas X SMA. Jurnal Pendidikan Ekonomi, 12(2), 104-110.

Handhika, J. (2012). Efektivitas Media Pembelajaran IM3 Ditinjau dari Motivasi Belajar. Jurnal Pendidikan IPA Indonesia, 1(2), 109-114. doi:10.15294/jpii.v1i2.2127

Marwati, M. (2018). Pengembangan Media Kokami Dalam Pembelajaran IPS Pada Siswa Sekolah Dasar. (R\&D di Kelas IV SDN PURUT Kecamatan Curug Kota Serang) (Doctoral dissertation, Universitas Islam Negeri SMH Banten).

Muhaiminah, M. (2018). Pengaruh Media Kokami (Kotak Dan Kartu Misterius) Terhadap Perkembangan Bahasa Anak Kelompok B RA Raudlatul Ulum Tebas Gondangwetan Pasuruan. SELING: Jurnal Program Studi PGRA, 1(1), 63-73. doi:10.29062/seling.v1i1.237

Qomariah, S. S., \& R Sudiarditha, I. K. (2017). Kualitas Media Pembelajaran, Minat Belajar, dan Hasil Belajar Siswa: Studi pada Mata Pelajaran Ekonomi di Kelas X IIS SMA Negeri 12 Jakarta. Jurnal Pendidikan Ekonomi dan Bisnis (JPEB), 4(1), 46. doi:10.21009/JPEB.004.1.3

Rusiana, Y. (2014). Penggunaan Media Kokami pada Mata Pelajaran IPA untuk Meningkatkan Hasil Belajar Siswa Kelas VA SDN Darungan 01 Kecamatan Tanggul Kabupaten Jember. Pancaran Pendidikan, 3(4), 183-192. Retrieved from https://jurnal.unej.ac.id/index.php/pancaran/article/view/1000

Sinurat, M., Syahputra, E., \& Rajagukguk, W. (2015). Pengembangan Media Pembelajaran Matematika Berbantuan Program Flash untuk Meningkatkan Kemampuan Matematik Siswa SMP. TABULARASA, 12(2). doi:10.24114/jt.v12i 2.3247

Suryadi, S. (2013). Pengaruh pembelajaran berbasis masalah berbantuan media kokami terhadap prestasi belajar fisika ditinjau dari kemampuan pemecahan masalah siswa SMA Negeri 1 Jember (Doctoral dissertation, Universitas Negeri Malang).

Turrahmi, N., Erfan, M., \& Yahya, F. (2017). Pengembangan Media Pembelajaran Video Berbasis Microsoft Office Power Point Pada Materi Objek IPA dan Pengamatannya. Quark: Jurnal Inovasi Pembelajaran Fisika dan Teknologi. doi:10.31227/osf.io/t6ky9

Wiyono, M. I. (2017). Pengembangan Media Pembelajaran Kotak dan Kartu Misterius (KOKAMI) pada Kompetensi Dasar Menjelaskan Cara Membuat Surat Niaga Siswa Kelas X APK 1 di SMKN 1 Bangkalan. Jurnal Pendidikan Administrasi Perkantoran, 5(3), 1-9. 
Zulham, M., \& Sulisworo, D. (2017). Pengembangan Multimedia Interaktif Berbasis Mobile dengan Pendekatan Kontekstual pada Materi Gaya. Jurnal Penelitian Pembelajaran Fisika, 7(2). doi:10.26877/ jp2f.v7i2.1308 